\title{
Ditadura Militar e resistência operária: O movimento sindical brasileiro do golpe à transição democrática
}

\author{
Marco Aurélio Santana*
}

\section{Introdução}

s anos de 1950 marcam um período de extrema importância para os trabalhadores brasileiros. O movimento sindical, liderado pela aliança das militâncias comunista e trabalhista, conseguiu grande avanço organizativo e mobilizatório, o que resultou em uma forte participação dos trabalhadores no seio da sociedade e na vida política nacional.

Após mais de uma década desse intenso crescimento e atividade, toda a estrutura organizacional dos trabalhadores brasileiros, na base e na cúpula, foi duramente atingida pelo golpe civil-militar de 1964, o qual tinha como uma das suas justificativas exatamente impedir a implantação de uma "república sindicalista" no país. A prisão de lideranças, a perseguição de militantes, bem como a desestruturação do trabalho nos sindicatos e nas fábricas, desbarataram atividades que levariam bastante tempo para serem recompostas. Em termos do movimento operário, o que restou, como tradicionalmente restava em períodos como esse, foi o trabalho pequeno e silencioso no chão de fábrica. Era preciso recompor forças e somar esforços para enfrentar a ditadura.

Doutor em Sociologia. Professor do Programa de Pós-Graduação em Sociologia e Antropologia da Universidade Federal do Rio de Janeiro (UFRJ). Publicou, entre outros, Homens partidos: comunistas e sindicatos no Brasil (São Paulo, Boitempo, 2001); tendo organizado também Trabalho e tradição sindical no Rio de Janeiro: a experiência dos metalúrgicos (Rio de Janeiro, Editora DP\&A, 2001) e Além da fábrica: trabalhadores, sindicatos e a nova questão social (São Paulo, Boitempo, 2003), com José Ricardo Ramalho. Endereço eletrônico: msantana@bridge.com.br. 
O problema maior é que a implantação do regime militar abriu, no seio da esquerda em geral, e no interior do até então partido hegemônico da esquerda em particular, o Partido Comunista Brasileiro (PCB), um duro e sério debate acerca dos caminhos percorridos antes e depois do golpe. Da crítica e autocrítica resultou uma série de outros grupos e concepções dos novos rumos a serem trilhados. O PCB, diante das posturas assumidas pré e pós golpe (com sua política de alianças e frente pela democracia), era responsabilizado e colocado em uma posição como que à margem do processo de luta das esquerdas. Enquanto o partido clamava pela organização de base e pela via pacífica de luta contra a ditadura e pela democracia, entrava em voga a via da luta armada como opção única de oposição ao regime. Um dado importante é que, contrabalançando a opção quase geral dos grupos de esquerda pela luta armada, o PCB optou por uma tentativa de penetrar na estrutura sindical da qual havia sido banido.

Ao longo desse período vão radicalizar-se algumas tendências em termos da economia que produzirão uma intensa transformação na face do país como um todo, e principalmente de sua classe operária. A intensificação da introdução de plantas industriais modernas e sua concentração geográfica (processo que se inicia em fins dos anos 50) vão possibilitar o surgimento do que se convencionou chamar de "nova classe operária". Ainda que não exclusivamente, serão esses os atores que despontarão mais tarde auxiliando na crise final da ditadura militar.

Esse artigo analisa a trajetória do movimento sindical brasileiro no período, dando ênfase aos fatores internos à vida desse movimento, entre os quais figuram as suas forças constitutivas e as disputas internas existentes em seu seio, as orientações político-ideológicas e suas influências na organização e nas práticas do mesmo, bem como as formas de luta empreendidas. Estarão em tela, também os fatores condicionantes externos, tais como as conjunturas políticas e econômicas, que servem de cenário para a ação do ator sindical, ao mesmo tempo modificando e sendo por esse modificado. 


\section{A ditadura militar e as novas tarefas sindicais}

Após o golpe civil-militar, a extensão das intervenções perpetradas pelo governo do general Castelo Branco (1964-1967), teve um alcance bastante grande, podendo ser sentida em todas as esferas da vida sindical, principalmente naqueles setores liderados pelos sindicalistas progressistas ${ }^{1}$.

Além de trabalhar nesse ataque direto às entidades, castrando-as de forma imediata, a ditadura vai também buscar atacar em termos do longo prazo, atuando sobre a legislação (ALMEIDA, 1975). O governo passa, por meio de uma série de medidas, a reforçar o caráter de controle sobre o movimento sindical, já presente previamente na Consolidação das Leis do Trabalho (CLT). Assim, estabelecem-se regras estritas para a ocupação do espaço sindical, com candidatos sujeitos à avaliação pelo Ministério do Trabalho e pela polícia política, e restringe-se o uso e o acesso aos recursos dos institutos de previdência, agora centralizados no Instituto Nacional da Previdência Social (INPS), cuja direção não se faria mais parcialmente sob o controle dos trabalhadores, como nos antigos institutos de pensão, e sim com a indicação direta pelo governo. No que diz respeito às mobilizações, apesar de uma suposta regulamentação e garantia do direito de greve, o que se deu de fato, foi a proibição do que seriam greves políticas e de solidariedade, quase que limitando a possibilidade de greves à cobrança de salários atrasados.

O primeiro governo militar vai implantar o Fundo de Garantia por Tempo de Serviço (FGTS). Esse dispositivo, que punha fim a estabilidade no emprego, incentivava diretamente a alta rotatividade de mão-de-obra por parte dos patrões e, correlatamente, dificultava uma ação sindical mais combativa a partir dos locais de trabalho.

1 "De fato, o governo interveio em $67 \%$ das confederações, em $42 \%$ das federações e em apenas $19 \%$ dos sindicatos. Organizações sindicais de bancários e trabalhadores em transportes figuraram de modo proeminente nas greves políticas, entre 1960 e 1964, e foram atingidas com maior intensidade, proporcionalmente, que os outros setores. E significativamente, os grandes sindicatos sofreram mais que os pequenos: o Ministério interveio em $70 \%$ dos sindicatos com mais de 5.000 membros; em 38\% dos com 1.000 a 5.000 membros; e em apenas $19 \%$ daqueles com menos de 1.000 membros. O governo militar simplesmente decapitou o movimento trabalhista radical" (ERICKSON, 1979, 209). 
Outro pólo de ataque da ditadura foi a tentativa de contenção da inflação via uma política de "arrocho salarial". Esta política foi sendo estabelecida aos poucos e quebrando a resistência encontrada entre setores da Justiça do Trabalho. Depois de muitos mecanismos intermediários para ultrapassar tais resistências, que acabavam por burlar sua política, o governo baixa um decreto lei, em meados de 1966, buscando regulamentar de forma rigorosa as determinações anteriores, tais como aquela que estabelecia que, caso os tribunais trabalhistas concedessem qualquer acordo salarial superior ao definido na lei, a percentagem que superasse as determinações oficiais seria subtraída do fator de inflação projetada para o acordo salarial seguinte.

De certa forma, serão estas duas perspectivas que marcarão os embates do movimento sindical nos anos vindouros. O Estado passa a alterar sua posição, no tocante tanto às questões trabalhistas como às questões sindicais. Ainda que também se pautasse pelo lastro da CLT, passava-se agora a dar realce aos seus ditames repressivos e de controle. Por não se propor a manter relações próximas aos sindicatos e relegando esses ao papel de controle sobre os trabalhadores, o Estado corta o canal de acesso em termos políticos que os sindicatos vinham tendo no período anterior e reforça a lógica assistencial naquelas entidades.

Com isso, não se visa propriamente o enfraquecimento dos sindicatos; antes, busca-se dar-lhes outro tipo de força. A idéia era fortalecer os sindicatos e o sistema corporativo para seu papel na construção da nação e da coesão social. Não é por acaso, portanto, que por meio dos dirigentes impostos aos sindicatos, visou-se tornar atrativa a filiação aos sindicatos, fornecendo mais benesses dos que as já dispostas na $\mathrm{CLT}^{2}$. A expansão do sistema corporativo vai atingir a área rural, onde, fechando as Ligas Camponesas e intervindo nos

2 Com isso, os associados passavam também a ter, entre outras coisas, "preferência em indicações para o serviço público, se ficam desempregados; em crédito no Banco Nacional de Habitação ou outras instituições oficiais para compra de sua casa própria; (...) na compra ou aluguel de apartamentos sob o controle do governo, quando vagos por decisão judicial; (...) e em bolsa de estudo para educação secundária ou treinamento técnico, para eles próprios ou para os filhos" (ERICKSON, 1979, p. 214). 
sindicatos mais atuantes, o governo espalha sindicatos oficiais sob o controle de líderes aprovados previamente.

Quanto às questões trabalhistas, as intervenções governamentais diretas, em termos das definições salariais, fazem com que o Estado transforme-se no centro do conflito. Claro que a batalha dos trabalhadores dava-se, ainda, no confronto com o patronato para soluções de seus problemas. Porém, como passa a determinar os limites dos aumentos salariais, o Estado atrai sobre si parte dos conflitos antes direcionados aos patrões. Desta forma, e mantendo os sindicatos sobre controle, o Estado passa a ser visto pelos trabalhadores não como um centro próximo, com o qual se pode ter contato imediato e travar negociações; mas, como mais um empecilho a ser vencido.

\section{A reestruturação da vida sindical e a pressão sobre os militantes}

Nas fábricas, os operários iam enfrentando como podiam a política de "arrocho salarial" e controle sindical da ditadura militar. Como já assinalamos, em termos concretos, a ditadura buscava uma reestruturação da vida sindical. Para tanto, ela tenta cortar os elementos e mecanismos da forma de funcionamento anterior. Além de intervir nas cúpulas sindicais, atacava duramente a estrutura de organizações nos locais de trabalho que podiam servir de pilar para a recomposição do movimento sindical "combativo".

Visando a dificultar ainda mais o caminho de recomposição do sindicalismo "combativo", o ministro do Trabalho de Castelo Branco, Arnaldo Sussekind, após autorizar a realização de eleições em centenas de sindicatos, elabora a portaria de № 40 . Tal portaria buscava limitar os acessos às direções dos órgãos sindicais, por indivíduos alheios à vontade do governo. Ela instruía os interventores a iniciar processos contra as direções depostas pelo golpe, por supostas irregularidades, impedindo-os, pelo exposto na portaria, de tentarem retornar ao sindicato via eleição.

Por todo o país, chapas independentes vão ter de lutar para formar sua chapa, vencer os interventores e conseguir assumir 
depois. Esta mobilização em termos da cúpula sindical tinha como lastro as mobilizações, ainda que surdas, nos locais de trabalho.

A visão de ocupação dos espaços, impedindo que os sindicatos fossem colocados a serviço do regime militar, assume lugar importante na preocupação de alguns grupos de esquerda, principalmente a militância do PCB. O partido conclama os militantes a participar de forma organizada das eleições sindicais, de reuniões, convenções e congressos, impedindo, juntamente com outras forças, a colaboração com a ditadura. Eles deveriam atuar nas entidades sindicais, mas tendo como centro a atividade nos locais de trabalho, levantando com ações unitárias a luta pelas reivindicações econômicas, políticas e sociais dos trabalhadores ${ }^{3}$.

O PCB, que, de certa forma, vê no espaço sindical o elemento chave de reativação do movimento operário, trabalha no sentido desse retorno aos sindicatos apesar dos limites a que estavam submetidos. Nesta luta os comunistas, como já fizeram em outras conjunturas, também vão travar batalhas contra os setores mais conservadores do movimento sindical. Além disso, eles trabalham no sentido da recuperação das entidades intersindicais, que possam articular de forma geral a luta dos trabalhadores.

No caso do enfrentamento com os setores conservadores, os comunistas atacam as posições da diretoria de interventores da Confederação Nacional dos Trabalhadores na Indústria (CNTI). Em setembro de 1965, a direção do órgão pronuncia-se contra a revisão dos níveis do salário mínimo, argumentando que isto acarretaria um aumento generalizado do custo de vida. Diante do suporte que a entidade vai concedendo às políticas do regime militar, o PCB define, como prática de contra ataque, que seus militantes sindicais deveriam organizar os trabalhadores e "desmascarar" esses elementos, verdadeiros "traidores" da classe.

3 Na verdade, esta visão do PCB acerca da ocupação dos espaços sindicais e da constituição das organizações por local de trabalho, estavam presentes também nas preocupações de outros setores da esquerda. Podemos indicar aqui pelo menos duas dessas posições já atuantes desde o pré-64. Uma defendida pela Política Operária (Polop) e a outra pela Ação Popular (AP). Ver FREDERICO (1987) e CARONE (1982). 
Nesta sua luta contra os setores mais conservadores, os comunistas vão denunciar as pressões e as tentativas de aliciamento que os dirigentes sindicais "mais combativos e honestos" vinham sofrendo. Segundo eles, no plano da pressão atuavam o Departamento de Ordem Política e Social (DOPS) e o Serviço Nacional de Informação (SNI). A ação desses órgãos vinha no sentido de coagir com ameaças as atividades sindicais (FREDERICO, 1987, p. 80).

No plano do aliciamento, entravam as entidades sindicais internacionais ligadas ao sindicalismo americano, que instalaram vários departamentos no Brasil, no período pós-golpe. Uma destas entidades, a Confederação Internacional de Operários e Sindicatos Livres (Ciosl), por exemplo, ofertava benesses aos interessados, tais como "diárias, passagens e outras vantagens aos dirigentes sindicais que desejarem ir aos Estados Unidos, ao México e a outros países onde lhes serão ministrados cursos cujas aulas estão impregnadas do anticomunismo" (idem, p. 81).

$\mathrm{Na}$ visão dos comunistas estas ações tinham como objetivo esvaziar as entidades sindicais, enfraquecê-las e transformá-las em simples órgãos de caráter assistencial. De órgão de unidade e de luta dos trabalhadores por seus direitos e reivindicações, a ditadura desejaria transformar as entidades sindicais dos trabalhadores em agências de "paz social".

\section{A esquerda e suas redefinições}

Estas características estabelecidas pelo regime militar serão importantes na conformação das identidades que o movimento sindical e suas tendências buscarão constituir nesse período. Outro elemento importante na constituição desta identidade seriam as orientações seguidas pelos grupos de esquerda que, embora por caminhos diferentes, tentaram estabelecer relações com o movimento dos trabalhadores.

Se, ao longo de toda a conjuntura 1945/1964, o PCB desfrutou da hegemonia em termos da representação não só dos trabalhadores, mas também dos setores de esquerda, esse quadro alteraria-se bastante a partir de meados dos anos 60 . Não estamos esquecendo 
aqui a contribuição que outros setores já vinham dando, de longa data, em termos da luta dos trabalhadores, entre os quais trotskistas, socialistas, trabalhistas etc. Porém, apesar de sua importância, nenhum desses agrupamentos atingiu o patamar conseguido pelo PCB. Seria só mais tarde, com os impactos do "racha" que deu origem ao Partido Comunista do Brasil (PC do B), em 1962, e de muitas outras defecções, bem como do surgimento e/ou reforço de propostas alternativas externas ao partido no pós-golpe, que o PCB começaria a perder o posto como referência na esquerda brasileira.

Com o golpe civil-militar, a esquerda inicia uma longa discussão pela busca de responsáveis pela derrota dos setores progressistas ${ }^{4}$. Devido à sua posição proeminente no período pré-1964, recai sobre o PCB, crítica e autocriticamente, toda a carga de responsabilidade acerca dos erros cometidos.

A esquerda fragmentava-se nos pós-1964, com rebatimentos no campo sindical. Ainda que de forma esquemática, pode-se dizer que duas posições enfrentavam-se por corações e mentes dos trabalhadores. Isto porque o PCB, até então hegemônico no sindicalismo nacional, vai enfronhar-se cada vez mais em sua relação com as direções sindicais pouco "combativas", e os setores mais radicais vão intensificar a busca de caminhos alternativos, seja no meio sindical ou na política mais ampla. A lógica de ação do $\mathrm{PCB}$, na grande política, era a conformação da frente democrática contra a ditadura. Já os setores mais à esquerda, com raras exceções, definiam-se pelo ataque frontal ao regime, baseado em ações de luta armada.

Mesmo que, devido às suas concepções políticas, muitas dessas organizações não mantivessem estreitos laços com o movimento operário, e menos ainda com o sindicalismo oficial, alguns desses grupos, seja por definição, seja por que ainda não haviam envolvido-se de corpo e alma na luta armada - o que fariam em escala crescente posteriormente -, vão desenvolver um trabalho que, a partir do interior das empresas e das Oposições Sindicais, al-

4 Segundo Aarão Reis Filho: "Nos anos 60 desenvolveu-se toda uma linha de reflexão sobre a "culpa" dos comunistas, que seriam os grandes responsáveis pelos erros e desacertos e derrotas do movimento popular" (1986, p. 52). 
cançou diretorias de sindicatos e promoveu movimentos grevistas de impacto no período. Marcado por ações arrojadas e radicais, o sindicalismo desenvolvido por esses grupos buscou romper, na prática, com as orientações seja dos tradicionais "pelegos", seja dos "reformistas" do PCB, e por isso granjeou suas críticas.

A divergência de concepções nas lutas desenvolvidas no pós-64, ficaram estampadas nos encaminhamentos das movimentações contra o "arrocho salarial" e contra a ditadura. O movimento operário e sindical no pós-64 vai travar uma árdua luta contra esta política. Muitas vezes, esta luta, que explodiu isoladamente em fábricas ou setores, não conseguiu evitar a repressão militar nem alterar em muito o quadro vigente. Em termos gerais, os encontros intersindicais propunham a mudança geral da lei do "arrocho", encaminhando abaixo-assinados como forma de luta.

\section{A política de arrocho salarial confrontada}

É nesse quadro de luta mais geral que surgem, por exemplo, a Frente Intersindical Antiarrocho, no Rio de Janeiro, o Comitê Intersindical Antiarrocho, em Minas Gerais, e o Movimento Intersindical Antiarrocho (MIA), em São Paulo. Embora de forma limitada e tímida, estas serão as mais importantes tentativas intersindicais desenvolvidas pelos trabalhadores nesse período. Elas decorrem dos sucessivos encontros regionais que desenvolveram a partir da Campanha Nacional de Proteção Contra a Política de Arrocho Salarial, definida pelo II Encontro Nacional de Dirigentes Sindicais, de 1967. Esta conferência, que se realizou sob o fogo cerrado da pressão da ditadura e contou, como sempre, com a oposição das direções da CNTI e da Confederação Nacional dos Trabalhadores no Comércio (CNTC), que se negaram a participar do encontro.

O caso mais expressivo e simbólico das distintas posições que se faziam sentir no movimento foi o MIA. Segundo os relatos de José Barbosa, em 1966 começou-se

"a discutir sobre o [...] que se poderia fazer contra a lei do arrocho. $\mathrm{O}$ movimento intersindical antiarrocho foi criado, pensado e articulado em São Bernardo. Nossa idéia primeira era reunir os dirigentes 
sindicais mais progressistas do $\mathrm{ABC}^{5}$ para um movimento conjunto contra a lei salarial" (Cadernos do Presente, 1978, p. 23).

A adesão de outros líderes sindicais à idéia do MIA deveu-se às supostas indicativas dadas pelo coronel Jarbas Passarinho, então Ministro do Trabalho do recém empossado governo Costa e Silva (1967-1969), que substituíra Castelo Branco na presidência, de que se opunha às leis de compressão salarial. Passarinho propunha, em termos sindicais, o que ele chamava de "renovação sindical". Com isso, vários setores mais conservadores também puderam integrar-se ao MIA supondo que haveria tolerância por parte do Estado (ERICKSON, 1979). Diante de uma conjuntura tendente à radicalização, em que seria difícil prever controles sobre os movimentos, como já vinha acontecendo, e sem querer por em risco seus postos na estrutura sindical, os "pelegos" irão trabalhar para que as ações do MIA não tomem vulto.

Além disso, outros fatores iriam contribuir para colocar a intersindical em dificuldades. Primeiro, a ação da vigilância policial, sempre alerta aos passos seguidos pela entidade. Segundo, havia desconfiança entre os diversos setores que compunham sua linha de frente. Terceiro, com a não aproximação das confederações e federações mais importantes ficou limitado o alcance da entidade. Por último, a forte pressão do movimento estudantil "que insistia em participar das reuniões sindicais para convocar os trabalhadores para a luta aberta contra a ditadura militar" (FREDERICO, 1987, p. 56).

\section{A greve em Contagem}

A chegada do ano de 1968 trará momentos marcantes para o movimento sindical. Como assinala Gorender (1987), esse "Já é um ano de franco ascenso econômico, o primeiro do 'milagre brasileiro', porém, a classe operária continua a sofrer os efeitos do arrocho salarial e de outras medidas compressivas do nível de vida” (1987, p. 142).

No dia 16 de abril, em um contexto de muitas demissões, falências de empresas e atrasos no pagamento dos salários, os ope-

5 Cinturão industrial da cidade de São Paulo. 
rários da siderúrgica Belgo-Mineira, situada em Contagem, Minas Gerais, paralisam suas atividades e vão concentrar-se na sede de seu sindicato. A ação grevista reivindicava um reajuste salarial acima do teto de $17 \%$ proposto pelo governo. Pode-se perceber claramente o trabalho "clandestino" dos grupos de esquerda, principalmente da Ação Popular (AP), da Corrente Revolucionária e do Comando de Libertação Nacional (Colina). A chapa identificada com esses setores ganhou as eleições sindicais em meados de 1967, mas alguns nomes, entre eles o cabeça de chapa Enio Seabra (presidente da entidade cassado em 1964), foram vetados pelo Ministério do Trabalho. Ainda assim, as organizações citadas continuaram influenciando as atividades do sindicato e começaram a desenvolver intenso trabalho de agitação nas fábricas. Sempre que puderam, utilizaram a estrutura do órgão nesta tarefa, sem que ficasse muito aparente, camuflando deliberadamente a participação do sindicato nas ações.

O trabalho da oposição foi sentido ao longo de todo o período após o golpe. Ela vai combater o interventor e avançar no trabalho de organização dentro das empresas, formando comissões. Estas comissões, chamadas "comissões de cinco", surgiram após o dissídio de 1967. Depois de sucessivos dissídios, nos quais os metalúrgicos haviam saído frustrados com o índice recebido, animados pelas organizações de esquerda, buscou-se dar caráter mais orgânico ao movimento.

A proposta das comissões espalhou-se por várias fábricas, entre elas a Belgo-Mineira, onde a greve foi deflagrada ${ }^{6}$. Nos primeiros dois dias, os operários ocuparam a empresa. Ainda que preparados para resistir à intervenção militar, diante da possibilidade da mesma, eles retiram-se da fábrica. Com três dias começam as adesões tais como a dos trabalhadores da Mannesmann, da Belgo-Mineira de João Monlevade e da Sociedade Brasileira de Eletrificação (SBE), com isso o movimento inicial de 1200 operários já contava com mais de 15 mil trabalhadores. O ministro Passarinho, após pronunciamento contra a "agitação" na greve, deslocou-se para a cidade em busca da

6 A organização da greve estava pensada para o duro embate que se daria em outubro, época da campanha salarial. Contudo, a dinâmica da conjuntura e dos grupos políticos acabou precipitando o movimento em abril. 


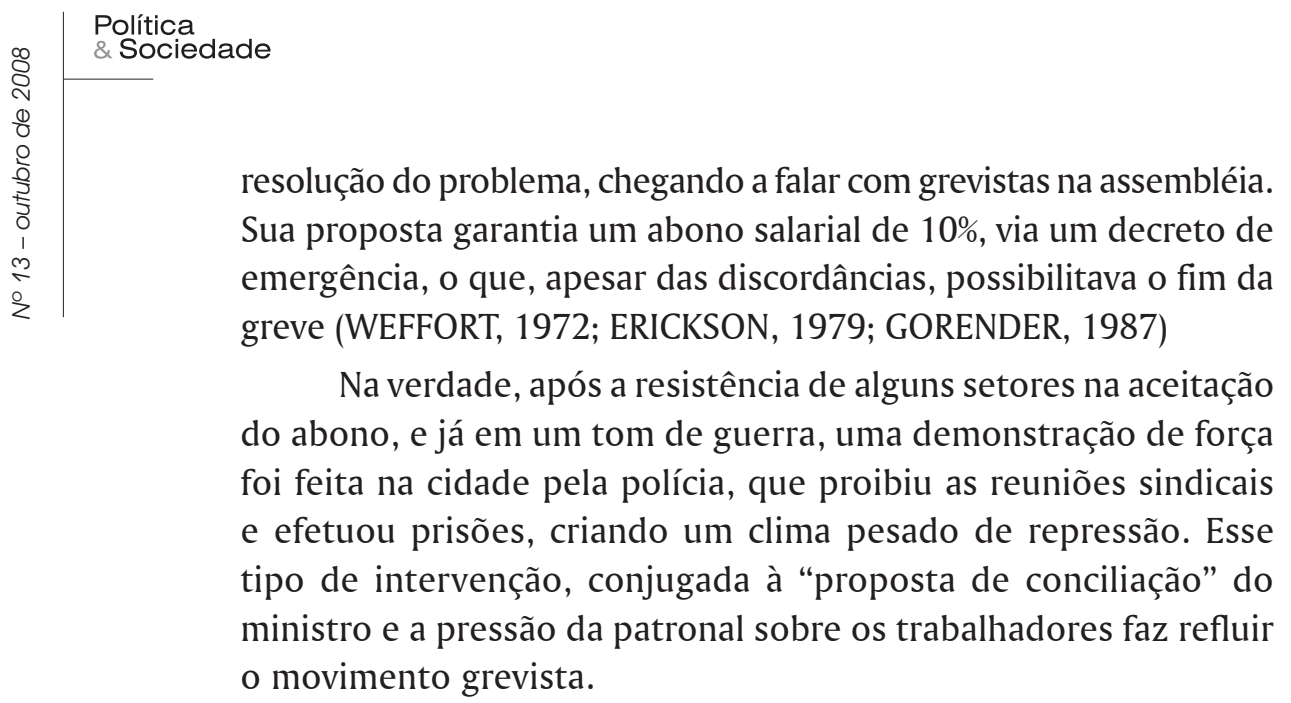

\section{As movimentações de Osasco}

Mas, se esse movimento refluía, outros já estavam a caminho. Nas comemorações do 1o de maio de 1968 na Praça da Sé, em São Paulo, a atenção nacional volta-se novamente para o movimento operário brasileiro. $\mathrm{O}$ evento assinalaria outro confronto entre os setores mais radicalizados do movimento e os setores que buscavam uma ação mais institucional.

No processo organizativo das festividades do 1ํ de maio, já despontavam as divergências simbolizadas nas posições defendidas pelo Sindicato dos Metalúrgicos de Osasco e as lideranças sindicais do MIA. O Sindicato dos Metalúrgicos de Osasco vai ser uma peça importante não só nesse episódio, como também na organização do processo grevista, que seria um dos marcos do período.

Em 1967, a chapa de oposição vence as eleições para a direção do sindicato. O presidente seria José Ibrahim. De modo geral, ele tinha sustentação de dois blocos. O chamado grupo de Osasco e a Frente Nacional do Trabalho. As raízes desse movimento de oposição remontam ao período pré-1964. A FNT foi criada em 1962 e tinha como base operários-cristãos congregados na Ação Católica Operária (ACO) e na Juventude Operária Católica (JOC). Ela opunha-se às diretivas do sindicato dirigido pelos comunistas e buscava realizar um trabalho no interior das empresas; segundo eles, abandonado pelo sindicato e suas preocupações de agitação política. Em 1963, 
um grupo de militantes do PCB, discordando das ações que consideravam "cupulistas" do partido e de seu sindicato, resolve deles afastar-se e ir realizar um intenso trabalho de organização na base. Começando pela empresa Braseixos, da qual eram egressos, terão influência em outras empresas de porte e importância como, por exemplo, a Cobrasma. O trabalho desse grupo era a constituição de "comitês clandestinos de fábrica".

O grupo ligado à FNT organiza, dentro da Cobrasma, uma comissão semi-legal de trabalhadores que pleiteou, inicialmente, o seu reconhecimento pela empresa, que respondeu com a dispensa dos mais engajados. Ao longo do processo, o grupo clandestino vai aproximar-se da comissão semi-legal. Mesmo a ação do grupo clandestino era a de atuar dentro do sindicato, ainda que reconhecendo seus limites como instrumento de luta.

É só após o golpe, e depois de embates com a direção da empresa, que os operários da Cobrasma conquistam o direito de eleger uma comissão de fábrica reconhecida pelos patrões e com imunidade para seus representantes. Membros do grupo clandestino foram eleitos, mas mantiveram seu trabalho como grupo clandestino, tendo em vista a possibilidade de retrocesso nas ações da comissão e dos patrões. A força majoritária era a FNT e ao longo do tempo as divergências vão aparecer, à medida que, para o grupo clandestino, a comissão enredara-se nas negociações de "cúpula" com a direção da empresa, "servindo de amortecedor entre patrões e operários". Intensificando seu trabalho e aproveitando-se do desgaste da FNT, o grupo clandestino vai ganhando cada vez mais espaços e consegue eleger grande parte dos membros da segunda comissão.

O trabalho de oposição à direção sindical vai intensificandose. Eles trabalham pelo fim da intervenção no sindicato e depois continuam a oposição à chapa eleita com os auspícios do interventor, que agrupara também membros da FNT. Segundo Ibrahim, o "nosso trabalho na Cobrasma nos deu uma grande autoridade para atuar nas assembléias sindicais e atrair para nossas posições os elementos de outras fábricas" (Cadernos do Presente, 1978, p. 10) ${ }^{7}$.

7 Esse trabalho vai consolidar o chamado grupo de Osasco Segundo Espinosa (Cadernos do Presente, 1978, p. 42-43), esta era apenas uma expressão criada 
O trabalho cresceu e a oposição credencia-se para uma chapa nas eleições sindicais de 1967. Como a visão do grupo clandestino era a de manutenção do trabalho na base, ele não pretendia diluirse no interior do sindicato. Só Ibrahim fará parte da chapa, como presidente. A posição de "confronto" defendida pela oposição na Cobrasma e a posição "legalista" da direção sindical, marcariam as linhas do processo. A oposição conseguiu a vitória na eleição.

Em termos gerais, a direção do sindicato busca articular-se com as lutas mais amplas do movimento operário e sindical brasileiro. É a partir desta perspectiva que o sindicato de Osasco passa a integrar o MIA. A participação do sindicato sempre se deu de forma crítica e tensa. A tensão entre Osasco e o MIA ficou patente em várias oportunidades. A principal delas deu-se nas comemorações do 1ํo de Maio de 1968 na Praça da Sé, em São Paulo. A posição majoritária do MIA era fazer um evento com a participação de figuras públicas e autoridades convidando, entre outros, o governador de São Paulo, Abreu Sodré. Para o grupo de Osasco deveriam tomar parte apenas trabalhadores, para que não se descaracterizasse a solenidade e não se identificasse as lideranças com o governo. Como a posição de Osasco não foi aceita, uma articulação se inicia no sentido de "tomar de assalto" o evento. E foi o que aconteceu. $\mathrm{O}$ ato oficializante, com boa afluência de trabalhadores, foi "tomado" por grupos de manifestantes que colocaram o governador do estado para fora, sob uma chuva de paus e pedras, tendo incendiado o palanque. Dali saíram em passeata até a Praça da República onde um comício foi realizado.

Os efeitos posteriores demonstram a ditadura tentando reverter o jogo. Muitos dos participantes não conseguiram permanecer nas fábricas em que atuavam. Alguns deles, que até então tinham vida legal, necessitaram passar à vida clandestina, paralisando os

posteriormente para designar "o conjunto de operários, operários-estudantes e estudantes que viviam em Osasco e atuavam nos movimentos locais. As relações que uniam o grupo eram informais, ou seja, ele não tinha caráter partidário. Um conjunto de definições vagas, entretanto, dava-lhe certa unidade”. Entre essas concepções estavam as comissões de empresa, o uso legal de todas as formas de organização, uma simpatia pela Revolução Cubana e pela luta armada. Esse grupo acabou por se identificar com a organização guerrilheira Vanguarda Popular Revolucionária (VPR). 
trabalhos na esfera em que vinham realizando. O clima imperante era de certa euforia com os desdobramentos que a conjuntura ia sofrendo, aparentemente indicando um enfraquecimento da ditadura e um ascenso dos movimentos de oposição.

Esse tipo de clima vai ter seu rebatimento no meio operário. Novamente Osasco tornar-se-á centro de precipitação de turbulência. Segundo relatos de Ibrahim (Cadernos do Presente, 1978), nos momentos seguintes ao primeiro de maio, a radicalização espalhouse por fábricas de Osasco. Era o início do processo que levaria a um dos mais importantes desafios operários no quadro de ditadura.

A greve de Osasco (WEFFORT, 1972; GORENDER, 1987), como ficou conhecida, foi bastante estruturada e planejada, ainda que se possa questionar alguma de suas avaliações. A perspectiva era ocupar fábricas de forma sucessiva, estendendo para toda Osasco, e depois para São Paulo. A visão dos planejadores era de que a repressão ao movimento demoraria um pouco, levando-se em conta as ações do governador Abreu Sodré com relação aos movimentos dos estudantes e a posição assumida pelo governo quando da greve de Contagem. Não foi o que aconteceu. Diante do crescimento das manifestações populares e do recuo que significou sua aceitação, ainda que relativa, das condições em Contagem, a ditadura reage rápido conjugando negociação e repressão. Apesar do clima de entusiasmo reinante, ao fim do primeiro dia uma forte repressão abateu-se sobre a cidade. Fábricas cercadas, prisões e tensão imperaram em Osasco. Na Cobrasma, foco maior de tensão, apesar dos apelos operários para que os soldados não invadissem a empresa, os militares o fizeram no final da noite daquele mesmo dia.

No segundo dia, apesar de toda a ocupação policial na cidade, outras fábricas tentaram parar, o que, diante da repressão, tornara-se bastante difícil. Nesta noite, o sindicato sofreu a ação da polícia que desocupou o prédio para que o interventor pudesse assumir seu papel, o que havia sido impedido pelos operários que ocupavam o sindicato. As lideranças que ainda não estavam detidas são caçadas pela polícia. A partir do quarto dia, já não se tinha mais controle sobre o movimento. Embora já sem lideranças, o movimento arrastase. As prisões estendem-se pelas igrejas, bairros etc. Já no sexto dia, as fábricas de Osasco funcionavam normalmente. 


\section{Os trabalhadores e os anos de chumbo}

Seriam de grande monta os impactos da greve e dos destinos de suas lideranças sobre o movimento de Osasco. Mesmo tendo mantido núcleos dentro das empresas, a articulação da oposição seria dificultada pelo fato da atenção jogada cada vez mais para o interior da organização de esquerda armada à que pertenciam, o que também faz com que muitos dos militantes mudem da cidade e/ou sejam presos por conta de ações do grupo.

Esse tipo de impacto ver-se-á também no segundo movimento de Contagem, deflagrado em outubro de 1968, tendo como base os grupos de esquerda dentro das empresas. Em uma escala repressiva da ditadura já em marcha, a segunda greve de Contagem sofreu dura repressão e resultou na intervenção no sindicato, encerrando o que seria o 1968 operário.

Ao fim de 1968 os passos do endurecimento do regime estavam lançados, e consolidam-se com a decretação, em dezembro, do Ato Institucional N. $5^{8}$. O "milagre econômico" ia deslanchando, os grupos de esquerda, com raras exceções, se engolfam cada vez mais nas ações armadas e o regime replica com mão de ferro. Para o movimento operário e sindical começa mais um momento de espera e ações subterrâneas. A situação agravar-se-ia com a chegada à presidência do general Emílio Médici (1969-1970). Seriam necessários mais dez anos para que o movimento operário viesse à tona novamente, abrindo uma de suas mais luminosas etapas.

É importante ressaltar que apesar da repressão feroz, com a prisão e tortura como práticas correntes, que intentava alcançar todas as partes, os militantes operários fizeram da fábrica seu locus privilegiado de ação. Esse tipo de alteração atingiu diversos setores envolvidos no trabalho sindical e pode ser sentida mesmo na prática dos militantes cristãos do ABC paulista. Para Martins (1994, p. 214), isto significou a "volta ao trabalho de fábrica, ao trabalho de bairro,

8 Esse Ato, entre outras medidas, fecha o Congresso Nacional, cassa mandatos de senadores, deputados, prefeitos e governadores, intervém no Poder Judiciário, decreta estado de sítio, intedita qualquer reunião, aumenta a censura e suspendeu o habeas corpus para "crimes" políticos 
procurando organizar equipes e levar adiante não só o movimento, mas, principalmente, a resistência ao sistema”.

No cenário sindical, a ditadura utiliza de todos os mecanismos para barrar os avanços ainda que tênues de qualquer posição mais contestadora. As tentativas de prosseguimento da luta sindical, sempre esbarravam com os limites estreitos da ditadura militar. Até os eventos de cunhos oficiosos, organizados por lideranças pouco "combativas", podiam ser palco das ações e violências policiais. Assim, os militantes sindicais trabalhavam em um território extremamente minado.

No plano dos encontros sindicais, os trabalhadores vão tentando maior articulação de suas demandas. Observando-se atas e pautas decorrentes dos vários encontros sindicais de categorias profissionais, podemos verificar que o enfrentamento da questão do "arrocho salarial" encontra-se ainda na ordem do dia. Os trabalhadores buscavam intensificar a luta por melhores condições salariais e de vida. Note-se entre esses: os encontros nacionais dos metalúrgicos, o encontro da CNTI, em novembro de 1970, e o da Confederação dos Trabalhadores em Estabelecimentos de Crédito (Contec), ocorrido logo depois. Os avanços sentidos em termos do trabalho no interior destas confederações, por exemplo, serão também alvo de ação do regime que, após vetar sucessivos nomes à direção da Contec, intervém na organização em 1972.

Todo esse trabalho silencioso e acobertado, que articulava diversos grupos em diversos setores, vai mantendo a chama do movimento operário-sindical brasileiro, apesar dos sucessivos ataques desfechados pelo regime. É em fins da década de 1970 que toda uma série de movimentações ganha visibilidade, rompendo os limites impostos pela ditadura aos trabalhadores. Isto ocorrerá com as mobilizações dos metalúrgicos do $\mathrm{ABC}$ paulista.

\section{O ascenso operário e o descenso da ditadura: o $A B C$ das greves}

O quadro de ascensão do movimento dos trabalhadores vai encontrar o regime militar repensando suas estratégias. $\mathrm{O}$ esgotamento do "milagre brasileiro", catapultado pela alta internacional 
dos preços do petróleo, no plano econômico, e as sucessivas derrotas eleitorais, com destaque para a de 1974, impuseram a ditadura um momento de inflexão e de alteração de rota. Vencida a luta armada, ainda que os resquícios da máquina repressiva fiquem expostos em ações que provocaram mortes e desaparecimentos, o governo militar a partir de 1974, com a chegada do general Ernesto Geisel (1974-1979) à presidência, propõe-se a estratégia da "abertura” política. Esse processo, garantindo a sobrevivência do regime, se daria de forma "lenta e gradual".

Mas, o movimento dos trabalhadores traria mais complexidade ao quadro. Como que um elemento surpresa, eles irromperam à cena e estremecem os arranjos que se pensavam sem eles. A sociedade brasileira vai reconquistando seus espaços de participação política. Vivendo um ambiente de efervescência, ela verá surgirem inúmeros movimentos sociais que irão pavimentando o caminho para o processo de redemocratização, acelerando a crise do regime militar (KRISCHKE, 1982; SADER, 1988). Dentre esses movimentos podem ser listados o estudantil, o de mulheres, o de bairros e o contra a carestia. Articulados ou não ao movimento sindical, os movimentos sociais, em seu conjunto, engrossarão a luta democrática do período. Esta luta terá nos trabalhadores um sólido sustentáculo.

Quando os metalúrgicos do ABC paulista entraram em greve em 1978, abrindo caminho para a paralisação que se seguiu em outras categorias, eles rompiam com os limites estreitos estabelecidos pela lei antigreve, com o "arrocho salarial" e o silêncio geral ao qual havia sido forçada a classe trabalhadora. Com isso, eles impactaram alguns dos pilares de sustentação política e econômica da ditadura militar.

Um dos fatores importantes para a deflagração do movimento foi, sem sombra de dúvida, a revelação pelo Banco Mundial de que o regime militar, em 1973 e 1974, maquilara os índices de inflação, mascarando o verdadeiro patamar do custo de vida (HUMPHREY,1982). Isto levou a que os trabalhadores fossem penalizados em 34,1\%. O sindicato dos metalúrgicos de São Bernardo do Campo, sob a presidência de Luiz Inácio da Silva, o Lula, começa uma campanha pela reposição salarial em busca daquilo que lhes havia sido 
retirado. Ainda que experimentasse o pouco interesse dos patrões e do governo no sentido da reposição, esta campanha semeará o terreno para as mobilizações futuras ${ }^{9}$.

A campanha salarial de 1978 nutrir-se-á desse solo fértil. A campanha desse ano, em si, não trazia nenhuma novidade. Ela termina como as anteriores, homologando-se os índices oficiais. Porém, o sindicato tinha como estratégia desmascarar todo o processo. É por isso que ele recusa-se à negociação tutelada pela justiça do trabalho, abrindo mão de sua participação no dissídio.

A política do sindicato, então, era trazer a público o que seria uma farsa de participação gerada pelo governo e deixar um vazio em termos da parte referente à representação dos trabalhadores. $\mathrm{O}$ sindicato, que, ao longo da campanha de reposição que precedeu a campanha salarial de 1978, já vinha batendo na tecla do roubo efetuado pelo governo, preparava o caminho para uma desilusão ainda maior ao término desta campanha.

Em fins de março, os trabalhadores da Mercedes-Benz já haviam paralisado o trabalho por não terem recebido o aumento que a empresa costumava conceder. O desenvolvimento da paralisação em vários setores da fábrica levou a demissão de 17 operários, fazendo o movimento refluir. A própria postura da empresa posteriormente indicava certa alteração nos padrões de negociação. $\mathrm{O}$ endurecimento era sensível.

Em 12 de maio de 1978, os trabalhadores da Saab-Scania entraram em greve. Na verdade, a Scania já havia passado em fins de 1977 por tensões internas entre a direção da empresa e seus empregados o que resultara na demissão de alguns operários. $\mathrm{O}$ sindicato reverteu as demissões na justiça, mas elas acabaram prevalecendo na prática.

A greve de 12 de maio de 1978 pegou o sindicato um tanto de surpresa. O movimento estendeu-se por quatro dias, findos os quais a diretoria do sindicato arranca um acordo "de boca" da direção da empresa; acordo que depois pressionada pelos outros setores da

9 Para uma análise desse e dos movimentos subsequientes no $\mathrm{ABC}$, ver, entre outros, Antunes (1988), Abramo (1999) e Paranhos (1999). 
indústria automobilística, a Scania não cumpriu, trocando os $20 \%$ das reivindicações por meros 6,5\%. Nova mobilização é tentada, mas, mediante as práticas repressivas da empresa, não efetivou-se.

Contudo, as mobilizações por fábrica já se alastravam pelo ABC paulista. No dia 15 de maio pára a Ford, e no dia 16 a Volkswagen. Apesar da posição do TRT de considerar as greves ilegais, isto foi o início de uma onda mobilizatória que alcançou grandes, médias e pequenas empresas, desenvolvendo tipos variados de greve e com duração diversa, alcançando outros municípios como Osasco e São Paulo. A mobilização atinge também outros setores da economia (ANTUNES, 1988), trazendo preocupação para todo o patronato e para o governo militar.

O ano de 1979 veria desenvolver-se e aumentar a participação dos trabalhadores no cenário político nacional. Desde a greve de 1978, o movimento desdobrara-se, espalhara-se e atingira diversas categorias e diversos estados, entre os quais centros importantes como Rio de Janeiro, Minas Gerais e Rio Grande do Sul. Mas é novamente no $\mathrm{ABC}$ paulista, entre os metalúrgicos, que novas situações de mobilização vão transcender os limites impostos e colocar a luta dos trabalhadores e a luta pela democratização do país em outro patamar.

A campanha salarial dos metalúrgicos do $\mathrm{ABC}$ trazia elementos novos. Além do reajuste salarial, eram reivindicadas também a garantia de emprego e a implantação de delegados sindicais no interior das empresas. Diante da preparação da mobilização pelos trabalhadores, os empresários começam a solicitar medidas punitivas por parte do governo em caso de greve. Esta mesma classe empresarial, acostumada à intransigência e ao acobertamento por parte do Estado, dava sinais de que viria mais preparada para o embate. A partir do dia 12 de março de 1979, mais de 50 mil trabalhadores metalúrgicos decidiram entrar em greve e paralisar o trabalho. Esta paralisação deu-se pleno processo de passagem do poder militar de Ernesto Geisel para João Figueiredo (1979-1985).

No dia 13 de março, grandes empresas como a Ford e a Volks já amanheceram paralisadas. No segundo dia de paralisação, ela já se estendera interior do estado e era considerada ilegal pelo 
governo. Apesar disso, os trabalhadores continuam com sua disposição de luta. Em seu quarto dia, a greve já conta com cerca de 170 mil trabalhadores paralisados em todo o $\mathrm{ABC}$, demonstrando todo o fôlego do movimento.

Já contando dez dias de paralisação, o Ministério do Trabalho tenta intervir no processo, apresentando uma proposta de conciliação que indicava a criação de uma comissão tripartite para estudar o reajuste em um prazo de 45 dias, a não demissão dos grevistas e o pagamento das horas paradas a serem descontadas mais tarde com parcelamento.

Tal proposta foi repudiada por 80 mil metalúrgicos de São Bernardo no Estádio de Vila Euclides, 30 mil em Santo André e 6 mil em São Caetano, em suas respectivas assembléias. A resposta do Ministério do Trabalho não se fez esperar. No dia 23 de março, foi decretada a intervenção nos sindicatos. Os momentos que se seguiram à intervenção foram marcados por muita tensão. Por diversas vezes, a massa de trabalhadores quase partiu para enfrentamento com as forças policiais em praça pública. Com seus espaços fechados, os trabalhadores passam a utilizar-se da Igreja Matriz para os encontros da liderança sindical e da comissão de salários.

O fato é que a intervenção ao mesmo tempo em que serviu de elemento radicalizador da massa, em vez de "pacificá-la", serviu também para deixar o movimento acéfalo. Embora Lula tenha dito que, em caso de intervenção, a comissão de salários assumiria o papel da direção, o mesmo não foi um processo fácil ou efetivo.

Após conversa e pressões de líderes sindicais (Arnaldo Gonçalves, presidente do Sindicato dos Metalúrgicos de Santos e membro do $\mathrm{PCB}$, por exemplo) e personagens públicas (a atriz Lélia Abramo, por exemplo), Lula e a direção resolvem reassumir a greve. O movimento já apresentava certo sinal de refluxo. Na terça-feira, dia 27 de março, em assembléia, seguindo avaliação do comando de greve, os trabalhadores aceitam um acordo com o patronato, que estabelecia o prazo de 45 dias para novas negociações em busca do índice satisfatório, findo o qual os metalúrgicos entrariam em greve mais uma vez. Ainda que com certa resistência na assembléia, a proposta foi aceita majoritariamente. 
Com o retorno a certa "normalização", o sindicato passava a retomada de suas atividades. Era uma verdadeira operação de guerra na qual os militantes sindicais intensificaram seu trabalho de porta de fábrica e de panfletagem. A lógica intransigente da ação patronal só seria quebrada quando, no $1^{\circ}$ de maio, 130 mil trabalhadores reiteram sua posição e indicam a deflagração de nova greve como fato iminente. No dia 12 de maio o sindicato celebra um acordo com a FIESP que será referendado no dia 13 de maio, por uma assembléia de trabalhadores.

O ano de 1980 trará novas movimentações no ABC. Como já haviam feito antes, os metalúrgicos iniciaram nova mobilização em sua campanha salarial, cobrindo os meses de abril e maio de 1980, a qual resultou em uma greve. Aos percentuais de aumento (reajuste salarial com base no Índice Nacional de Preços ao Consumidor (INPC) mais $15 \%$ a título de produtividade), integrar-se-iam outras reivindicações como: a da garantia no emprego, a do salário profissional, a conquista do delegado sindical, a redução da jornada de trabalho para 40 horas sem redução salarial e o controle das chefias pelos trabalhadores.

Como já esperado, as contrapropostas vieram bem abaixo do solicitado: $3,65 \%$ de aumento acima do INPC, o piso salarial oferecido era a metade do reivindicado e as outras reivindicações referentes à estabilidade, à redução de jornada, aos delegados sindicais e aos controles das chefias, foram todas negadas. O índice de aumento ainda foi elevado para $5 \%$, com os prenúncios do movimento grevista.

No dia 30 de março, os metalúrgicos do $\mathrm{ABC}$ decidiram paralisar suas atividades a partir do dia seguinte, 10 de abril de 1980. Já nesse dia, em São Bernardo, a greve contava com a adesão de $90 \%$ da categoria. Nesse mesmo primeiro dia, o TRT julgou-se incapaz de decidir sobre a legalidade ou não da greve e elaborou uma proposta alternativa, que não contemplava o interesse dos trabalhadores paralisados. Esta proposta fez com que os metalúrgicos de Santo André e São Caetano aceitassem o estabelecido e acabassem com a sua participação na greve. Quanto aos metalúrgicos de São Bernardo do Campo, ainda que reconhecendo certa vitória, não aceitaram os termos estabelecidos e continuaram seu movimento, ainda com $90 \%$ de adesão. 
Apesar da saída de outros sindicatos, no oitavo dia de greve, a empresa Termodinâmica, cedendo à negociação, dava indícios de que o desfecho estaria próximo. Mas não estava. Um segundo julgamento do TRT invalidou as decisões do primeiro e decretou a ilegalidade da greve. Com a ilegalidade da greve decretada, já havia respaldo legal para as ações repressivas que se sucederam.

No dia 17 de abril de 1980, o governo militar interveio nos sindicatos de São Bernardo do Campo e de Santo André. O ministro do Trabalho Murilo Macedo, que já havia efetivado intervenções em outros sindicatos, não se conteve com a intervenção e a cassação das lideranças do movimento. Os líderes grevistas e outras personalidades representantes de associações liberais foram presos. Os metalúrgicos haviam preparado-se bastante, em termos de estruturação, em caso da quase certa intervenção. Além de receberem solidariedade vinda de todo o país. Com os primeiros ataques do governo, as estruturas de apoio que haviam sido criadas começam a desempenhar seus papéis. Por sua vez, o governo e os empresários sabiam da importância da mobilização que enfrentavam, à medida que um sucesso desta greve traria o incremento do movimento sindical, já sentido a partir de 1978 e 1979. Os metalúrgicos sem seu sindicato, como já haviam programado, reúnem-se no Estádio de Vila Euclides e Paço Municipal em São Bernardo e no Estádio da Vila Jaçatuba em Santo André, e, com a proibição de assembléias pelo governo, na Igreja Matriz e nos bairros. Entrando na terceira semana de greve, os metalúrgicos tentam manter o ímpeto do movimento. A esta altura já haviam adicionado às reivindicações anteriores a exigência da libertação dos presos e do fim da intervenção nos órgãos de classe.

O governo endurecia reduzindo os espaços possíveis de reunião, dentre os quais sobraram apenas os espaços internos da Igreja. Os empresários, por seu turno, reforçavam as práticas repressivas e de persuasão. Os confrontos entre operários e as tropas policiais não eram raros dentro do cenário. Já se podia perceber um movimento de retorno esparso ao trabalho. Ainda assim, no 1 o de maio de 1980, que reuniu mais de 100 mil metalúrgicos em uma das maiores demonstrações operárias da história do país, os trabalhadores retomam o Estádio de Vila Euclides - já então um ícone das greves -, dando novos ânimos ao movimento. Mas o 
refluxo da mobilização começava a ser sentido. Logo no início de maio, os metalúrgicos de Santo André decidiram voltar ao trabalho e encerrar sua participação no movimento.

Já apresentando sinal de desgaste, os metalúrgicos do $\mathrm{ABC}$ põem fim ao seu movimento grevista que durou 41 dias. Lula e outras lideranças permaneceram presos por mais alguns dias, gerando campanhas nacionais por sua libertação e contra sua condenação. Um recurso apresentando pelo advogado do Comitê Brasileiro pela Anistia (CBA), consegue o relaxamento da prisão preventiva. Os sindicalistas acabaram sendo processados com base na Lei de Segurança Nacional (LSN), em julgamento por tribunal militar que se realizou no início de 1981.

A pressão sobre esta greve e seu resultado adverso aos trabalhadores teve grande impacto sobre o movimento sindical nacional e suas perspectivas mobilizatórias no início dos anos 80. Isto se inseria, também, no problemático quadro de distensão política pela qual passava a regime militar, que ia mostrando seus limites. Porém, essa greve, como as anteriores, marcaria a história política e sindical recente do país, se tornaria um ponto de orientação para os movimentos futuros e seria a porta de entrada de uma década de numerosas paralisações de trabalhadores e do florescimento de outros movimentos sociais que articuladamente ou não ao movimento sindical, darão contribuição importante para a entrada de novos personagens em cena (SADER, 1987; 1988).

\section{Os anos de 1980: mobilização sindical e transição democrática}

Esta sucessão de greves foi de grande relevância para o movimento dos trabalhadores, em particular, e para a sociedade, em geral, já que demonstrava sua capacidade de organização, mobilização e disposição de luta, ainda que frente ao temível regime militar. Após a greve de 1978, por exemplo, tornaram-se possíveis outras mobilizações, em um processo que se consolida e amplia-se com as greves de outras categorias (bancários, petroleiros, professores etc.) em todo o país, em uma verdadeira ascensão da classe trabalhadora no Brasil do período (SANTANA, 2001). 
A riqueza desse ressurgimento dos trabalhadores no cenário político nacional pode ser constatada, entre outras coisas, na fundação de um partido político, o Partido dos Trabalhadores (PT), em 1980, e na criação, pouco tempo depois, de organismos intersindicais de cúpula. $\mathrm{O}$ retorno dos trabalhadores foi marcado, também, pelo aparecimento do que se convencionou chamar de "novo sindicalismo", supostamente caracterizado por práticas que indicariam sua novidade na recente história sindical brasileira (SANTANA, 1999). Desta forma, os trabalhadores foram escrevendo seu nome na luta pelo retorno do regime democrático no Brasil.

Contudo, como vimos, apesar de seu sentido enfraquecimento, a ditadura ainda tentou conter a emergência do movimento dos trabalhadores da forma que pode. Por exemplo, o governo do general Figueiredo promoveu intervenção em sindicatos (como o dos metalúrgicos do $\mathrm{ABC}$ paulista e dos bancários de Porto Alegre) e a prisão de militantes e direções sindicais.

Mas os militares não tinham muito mais fôlego para impedir que a sociedade brasileira, em geral, e os trabalhadores, em particular, fossem reconquistando seus direitos. O sentido avanço e expansão do movimento sindical deságuam na busca de uma unificação, que o fortalecesse e desse-lhe uma coordenação nacional. Porém, esse processo vai explicitar as subjacentes tensões acerca das práticas e orientações seguidas pelos grupos envolvidos.

De forma geral, podemos caracterizar dois blocos ao longo do processo (RODRIGUES, 1991). De um lado, os chamados sindicalistas "autênticos" reunidos em torno dos sindicalistas metalúrgicos do $\mathrm{ABC}$, agregando sindicalistas de diversas categorias e partes do país, os quais, com os grupos integrantes das chamadas "Oposições Sindicais" 10 , que compunham o autodenominado bloco "combativo". Tendo sindicalistas como Lula (metalúrgicos de São Bernardo),

10 Agrupando militantes egressos ou não da experiência da luta armada e/ou militantes ligados à Igreja progressista, esse setor defendia o combate à estrutura sindical corporativa a partir de um intenso trabalho de base via comissões de fábrica. Sua maior expressão estava na Oposição Sindical Metalúrgica de São Paulo (OSM-SP) e podia apresentar posições que iam desde a aceitação do trabalho conjunto com o sindicato oficial, até aquelas contrárias a esse tipo de articulação. 
Olívio Dutra (bancários de Porto Alegre) e Jacó Bitar (petroleiros de Campinas), como nomes de ponta, esse setor formaria a base do chamado "novo sindicalismo". De outro, a "Unidade Sindical" que agrupava lideranças tradicionais no interior do movimento sindical (muitas delas vinculadas ao setor conservador do sindicalismo, denominado "pelego"), e os militantes de setores da esquerda dita "tradicional", tais como o PCB, o PC do B e o Movimento Revolucionário 8 de Outubro (MR8).

Fatores de ordem sindical e política desempenharam seu papel na recomposição das forças que disputavam a liderança do movimento que emergia. É preciso notar que nos primórdios desses movimentos, setores que posteriormente formarão a "Unidade Sindical" caminharam em aproximação com os chamados sindicalistas "autênticos". Um dos marcos de surgimento do sindicalismo "autênticos" foi o V Congresso da CNTI, em 1978, quando um grupo de sindicalistas opôs-se às orientações dos setores "pelegos" na direção confederação. Desse grupo constavam nomes associados tanto ao que seria o "novo sindicalismo", como nomes relacionados à chamada esquerda "tradicional".

Esta aproximação se dava à medida que aqueles setores, apesar das divergências, buscavam se movimentar no interior da estrutura sindical corporativa, já que eram todos membros de direções sindicais e, portanto, eram oriundos e atuavam dentro da estrutura. Ao longo da conjuntura as divergências acerca das relações do movimento sindical com a estrutura sindical e quanto à participação das "Oposições Sindicais" e de setores populares no interior de seus movimentos, entre outras, fez com que esses militantes, que se identificarão com a "Unidade Sindical", fossem se afastando dos "autênticos". Por seu lado, a aproximação cada vez maior dos sindicalistas "autênticos" com os setores de oposição sindical, em um arranjo que também não se deu sem tensões, garantiu a distinção definitiva dos blocos que acabará por desaguar, em meados dos anos de 1980, na constituição de centrais sindicais em separado.

Em 1981 eles conseguem realizar uma Conferência marcante na área sindical daquela conjuntura. A Conferência Nacional das Classes Trabalhadoras (Conclat), e que foi o primeiro e único gran- 
de evento a reunir todas as forças sindicais do período (Menezes e Sarti, 1981). Dali sairia a Comissão Nacional Pró-CUT e a proposta de realização de uma nova Conclat em 1982. Ela não se realizará, sendo adiada sob os argumentos da "Unidade Sindical" de que, sendo um ano eleitoral, dividir-se-iam as atenções, energias e o movimento dos trabalhadores. Jogada para 1983, a CONCLAT seria vítima da tensão crescente entre os setores sindicais.

A definição do afastamento dos dois blocos existentes vai tomando contornos cada vez mais nítidos. As contradições entre os setores da "Unidade Sindical" e da Anampos (a Articulação Nacional dos Movimentos Populares e Sindicais, nova sigla que abrigava a articulação dos "autênticos", "oposições sindicais" e outros setores dos movimentos populares), pareciam chegar ao limite possível da convivência ${ }^{11}$.

Um ponto central desta divergência, e o que na verdade fez com que o processo de separação se deflagrasse, foi a discussão em termos dos estatutos para a participação no Conclat vindouro, então adiado para agosto de 1983. A "Unidade Sindical", coerente com sua orientação e inserção, e buscando garantir seu controle, enfatizava a perspectiva da participação de delegados egressos das entidades sindicais; já a Anampos, intentando ampliar seus espaços de atuação e enfraquecer a "Unidade Sindical", reforçava a perspectiva da ampliação destes critérios visando à incorporação de delegados dos possíveis setores de oposição nos sindicatos.

A reunião da Comissão Nacional Pró-CUT, de 7 de agosto de 1983, deliberou a possibilidade de delegados serem eleitos em reuniões paralelas às entidades sindicais. Os setores da "Unidade Sindical" reagiram contra tal deliberação. A Contag, outras confederações, federações e sindicatos tornaram pública sua posição de que não participariam de um congresso que privilegiasse as "Oposições Sindicais", em detrimento das entidades sindicais. Tal postura fez com que o congresso ainda fosse adiado pelo menos duas vezes (Voz da Unidade, 19/08/83).

11 Para uma análise mais detalhada desse processo e seus desdobramentos ver, entre outros, Giannotti \& Neto (1991), Zanetti (1995), Rodrigues (1997) e Santana (2001). 
Mas, o processo de separação já ia adiantado. Uma reunião, em São Paulo, no dia 11 de agosto de 1983, contando com mais de 60 sindicatos, 14 federações e 5 confederações, buscou dar conta dos problemas referentes aos encaminhamentos do Conclat. Nada ficou acertado. Os setores vinculados à Anampos decidem realizar o Conclat na data prevista (26, 27 e 28 de agosto de 1983). Este Congresso realizar-se-ia em São Bernardo do Campo, São Paulo. Diante da efetivação da ruptura, convocada pela Anampos, os setores da "Unidade Sindical" resolvem chamar um outro congresso para os dias 4, 5 e 6 de novembro de 1983, em Praia Grande, São Paulo. O congresso realizado em São Bernardo funda a Central Única dos Trabalhadores (CUT). Aquele de Praia Grande, seguindo a proposta do $\mathrm{PCB}$, opta por não criar uma outra central sindical, o que configuraria a divisão. Assim, criou-se a Coordenação Nacional da Classe Trabalhadora (Conclat), que não contemplava os comunistas em sua executiva. Será assim, dividido entre tais vertentes que o movimento sindical brasileiro entrará na década de 80 , um período extremamente rico de sua história político-organizacional.

Em meados da década de 1980, o País ia deixando para trás longos anos de ditadura militar (1964-1985). O sindicalismo nacional, facilitado por um período de transição política para a democracia - que ajudara a conquistar e que lhe garantia campo de atuação - e por uma conjuntura econômica de elevada inflação - que lhe fornecia combustível mobilizatório -, acumulou vitórias organizativas importantes, reocupando o espaço político do qual havia sido privado pelos governos militares. Em seu conjunto, o sindicalismo brasileiro viverá no período o que pode ser considerado um de seus momentos de ouro, uma "década sindical". Qualquer balanço de sua trajetória naqueles anos deve apontar para três de suas características: a rápida consolidação no plano organizacional e a pujança mobilizatória, bem como sua importância na luta pela democratização do país, espelhada, entre outras, em sua participação no movimento por eleições livres e diretas para presidente (o Diretas Já) e pelo estabelecimento de uma Assembléia Nacional Constituinte. Em 1985 é eleito, por via indireta, no parlamento, o primeiro governo civil pós-1964. Ele poria fim aos governos militares, vinte e um anos depois. 


\section{Considerações finais}

Uma análise geral das ações dos trabalhadores durante a ditadura indica que uma série de mudanças estabeleceu-se. No plano mais geral, o capitalismo se redefine no País, produzindo mudanças substantivas na produção e no mundo do trabalho, o que traria óbvias alterações na composição das classes trabalhadoras.

Além disso, o regime militar buscou redefinir e limitar as ações mais progressistas no seio sindical. Tal estratégia só foi bem sucedida em certos momentos, não sendo capaz de imobilizar tais setores como o desejado. A luta dos trabalhadores, apesar das claras dificuldades, de uma forma ou de outra, não cessou um só momento, não dando tréguas aos patrões e aos militares.

Por seu turno, a esquerda passou por sensíveis mudanças de orientação, com claros rebatimentos em suas ações nos sindicatos. Muitas foram as disputas e diferenças entre os setores militantes ao longo do período atravessado, no sentido da luta pela direção do movimento dos trabalhadores. Ao fim do período, um novo setor assumirá a hegemonia do sindicalismo passando a orientar a parcela mais significativa, organizada e ativa do movimento.

Assim, se o trabalho importante e silencioso dentro das empresas mantinha a chama da resistência acesa, foi a partir de seu ressurgimento na cena política e de sua re-organização nacional que os trabalhadores contribuíram sobremaneira para o fim da ditadura no Brasil.

\section{Referências}

AARÃO REIS FILHO, D. Questões históricas (exposição). In: GARCIA, M. (org.). As esquerdas e a democracia. Rio de Janeiro: Paz e Terra/ Cedec, 1986.

. A maldição do populismo. Linha Direta, São Paulo, n. 330, setembro, 1997.

ABRAMO, L. O resgate da dignidade: greve metalúrgica e 
subjetividade. Campinas: Unicamp, 1999.

ALMEIDA, M. O sindicato no Brasil: novos problemas, velhas estruturas. Debate e Crítica, São Paulo, n. 6, julho, 1975.

ANTUNES, R. A rebeldia do trabalho. Campinas:Ensaio, 1988.

BOITO JR., A. (org.). O sindicalismo brasileiro nos anos 80. Rio de Janeiro: Paz e Terra, 1991.

Cadernos do Presente. Greves operárias (1968-1978). Cadernos do Presente, n. 2, Belo Horizonte: Aparte, 1968.

CARONE, E. O PCB: 1964/1982. São Paulo: Difel, 1982.

ERICKSON, K. Sindicalismo no processo político no Brasil. São Paulo: Brasiliense, 1979.

FREDERICO, C. A esquerda e o movimento operário: 1964/1984. v. 1. São Paulo: Novos Rumos, 1987.

. A esquerda e o movimento operário: 1964/1984. v. 2. Belo Horizonte: O. de Livros, 1990.

GIANNOTTI, V. \& NETO, S. CUT ontem e hoje. São Paulo: Vozes, 1991. GORENDER, J. Combate nas trevas. São Paulo: Ática, 1987.

HUMPHREY, J. As raízes e os desafios do "novo" sindicalismo da indústria automobilística”. Estudos Cebrap, n. 26, São Paulo: Cebrap, 1980.

. Fazendo o milagre. Petrópolis: Vozes/CEBRAP, 1982.

KRISCHKE, P. Brasil: do "milagre” à "abertura”. São Paulo: Cortez, 1982.

MARONI, A. A estratégia da recusa. São Paulo: Brasiliense, 1982.

MARTINS, H. Igreja e movimento operário no ABC. São Paulo: Hucitec, 1994.

MENEGUELLO, R. PT: a formação de um partido. Rio de Janeiro: Paz e Terra, 1989.

MENEZES, C. \& SARTI, I. Conclat 1981: a melhor expressão do sindicalismo brasileiro. Campinas: Cartograf, 1981.

MOISÉS, J. Lições de liberdade e opressão: o novo sindicalismo e a política. Rio de Janeiro: Paz e Terra, 1982. 
OLIVEIRA, I. Trabalho e Política. Petrópolis: Vozes, 1988.

PARANHOS, K. Era uma vez em São Bernardo: o discurso sindical dos metalúrgicos - 1971/1982. Campinas: Unicamp, 1999.

RODRIGUES, I. Sindicalismo e política: a trajetória da CUT. São Paulo: Scritta/FAPESP, 1997.

RODRIGUES, L. As tendências políticas na formação das centrais sindicais, In: BOITO, J. (org). $\mathbf{O}$ sindicalismo brasileiro nos anos 80 . Rio de Janeiro: Paz e Terra, 1991.

SADER. E. Quando novos personagens entraram em cena. Rio de janeiro: Paz e Terra, 1988.

. (org.) Movimentos sociais na transição democrática.

Rio de Janeiro: Cortez, 1987.

SANTANA, M. Entre a ruptura e a continuidade: visões da história do movimento sindical brasileiro. Revista Brasileira de Ciências Sociais, São Paulo, n. 41, 1999.

. Homens partidos: comunistas e sindicatos no Brasil.

São Paulo: Boitempo, 2001.

VIANNA, L. A classe operária e a abertura. São Paulo: Cerifa, 1983.

WEFFORT, F. Participação e conflito industrial: Contagem e Osasco, 1968. São Paulo: Cebrap, 1972.

ZANETTI, L. O novo sindicalismo brasileiro: características, impasses e desafios. Rio de Janeiro: Fase, 1995. 
